\title{
PROGRAM PENINGKATAN KEMAMPUAN ORANG TUA DAN GURU DALAM MEMBANTU KEMANDIRIAN SHOLAT ANAK TUNAGRAHITA RINGAN
}

\author{
Tarsono \\ Fakultas Psikologi UIN Sunan Gunung Djati Bandung, Jl. A.H Nasution No. 105 Bandung \\ email: tarsonomakmuri@yahoo.co.id
}

\begin{abstract}
Abstrak
Penelitian ini bertujuan membantu kemandirian sholat anak tunagrahita ringan dengan membuat saran bagi orang tua dan guru. Pendekatan kualitatif dengan wawancara, observasi, dan studi dokumentasi dilakukan dalam pengumpulan data. Hasil penelitian menunjukkan bahwa anak tunagrahita ringan belum dapat melakukan sholat lima waktu dengan bacaan dan gerakan yang benar. Orang tua dapat mengajak sholat berjamaah, mengundang guru ngaji dan memberikan bantuan lewat media. Sedangkan guru dapat membuatkan jadwal sholat berjamaah dan membuat alat peraga. Kendala yang dialami adalah kurangnya pemahaman tentang ketunagrahitaan, belum adanya alat peraga yang tepat, serta kurang perhatian terhadap ATGR.
\end{abstract}

Kata kunci: program, bimbingan sholat, anak tunagrahita ringan,

\section{Abstract}

This research aims to help mentally disabled students to pray independently by giving suggestion to parrents and teachers. Qualitative approach using interview, observation and documentation are used to collect data. Result shows that some mentally disabled students have not been able to have five times praying with correct reading prayer and movement. Parents can ask to pray together, invite teacher and provide some media. Meanwhile, teacher could make schedule for praying together and make a realia. Constraints faced are lack of mentally disabled knowledge, no appropriate realia and lack of attention toward mentally disabled students.

Keywords : program, praying guidance, mentally disabled students

\section{PENDAHULUAN}

Langgulung (1995:57) mengatakan bahwa manusia yang dianggap sebagai khalifah Allah tidak dapat memegang tanggung jawab sebagai khalifah kecuali kalau ia diperlengkapi dengan potensipotensi yang membolehkannya berbuat demikian. Oleh karena itu selaku hamba dan khalifah, manusia telah diberi kelengkapan kemampuan jasmani (fisiologis) dan rohaniah (mental psikologis) yang dapat ditumbuhkembangkan seoptimal mungkin, sehingga menjadi alat yang berdaya guna dalam ikhtiar kemanusiaannya untuk melaksanakan tugas pokok kehidupannya di dunia.

Islam telah mewajibkan kepada para pemeluknya untuk melaksanakan sholat lima waktu. Allah telah menggariskan tentang kewajiban sholat bagi umat manusia. Sholat itu wajib bagi setiap 
manusia, baik itu manusia kaya, miskin, utuh, ataupun cacat.

Pendidikan merupakan salah satu media yang sangat penting untuk mengoptimalkan potensi yang dimiliki manusia. Pelaksanaan pendidikan bukan saja di sekolah tetapi juga di keluarga. Keluarga adalah tempat yang pertama dan utama untuk memberikan pendidikan pada anak.

Astati (2002:2) mengatakan bahwa keluarga adalah sekelompok orang tua atau beberapa orang yang tinggal bersama dalam suatu rumah tangga dikarenakan adanya ikrar suci atau adanya ikatan darah. Hal senada juga dikatakan oleh al-Ghazali (1983:5) bahwa keluarga merupakan unit terkecil yang menjadi sendi dasar utama bagi kelangsungan dan perkembangan suatu masyarakat, bangsa dan negara.

Tugas dan tanggung jawab orang tua sangatlah penting dalam mendidik anak, sebab orang tua merupakan figure utama bagi anaknya. Oleh karena itu, orang tua harus memiliki kemampuan dalam memahami perkembangan anaknya, apalagi anak tunagrahita ringan.

Anak Tunagrahita Ringan adalah bagian minoritas dari manusia pada umumnya, karena keterbatasan dalam intelektualnya. Mereka mengalami hambatan dalam melakukan berbagai kegiatan, termasuk melakukan sholatnya.

Dalam kehidupan di keluarga masih terdapat kecenderungan pola asuh yang kurang memperhatikan prinsip-prinsip psikologis dan paedagogis. Tampilan sikap tersebut misalnya sikap orang tua yang terlalu melindungi anaknya dalam segala hal.

Anak Tunagrahita Ringan merupakan manusia yang memiliki kelainan intelektual (IQ). Oleh karena itu, layanan kepada anak Tunagrahita Ringan ini berbeda dengan anak pada umumnya (yang memiliki intelektual cukup baik). Salah satu tugas pokok sekolah (Sekolah Luar Biasa) adalah membantu siswa untuk mencapai perkembangan yang optimal sesuai dengan tingkat dan jenis kelainanya. Seorang siswa dikatakan berhasil mencapai perkembangan yang optimal apabila ia dapat menggunakan semua kemampuannya secara optimal sesuai dengan derajat ketunaannya.

Ketidakberhasilan dalam pendidikan tersebut tidak semata-mata karena ketunaan yang disandang siswa, tetapi ada juga yang karena ketidakmampuan pelaksanaan pendidikan untuk mendekati secara individual, sehingga dapat mengetahui berbagai hambatan yang mereka hadapi. Untuk itu mereka perlu diupayakan dan dibantu untuk mengatasi berbagai hambatan tersebut, melalui bimbingan konseling.

Bimbingan dan Konseling diperlukan bagi anak luar biasa. Suhaeri (1996:26) mengatakan bahwa Bimbingan dan Konseling adalah proses pemberian bantuan kepada individu agar individu tersebut dapat memahami dirinya, mengarahkan dan merealisasikan diri, sehingga dapat mencapai kebahagiaan hidupnya.

Sesuai dengan temuan di lapangan ketika penulis melakukan observasi kepada orang tua dari Anak Tunagrahita Ringan yang sudah bisa melakukan sholat sesuai dengan ketentuan, maka bimbingan dari orang tua memiliki pengaruh yang cukup besar dalam menumbuhkan kesadaran anak tunagrahita ringan untuk sholat.

Berdasarkan temuan di lapangan melalui wawancara dengan kepala sekolah SLB-BC Sumber Sari Antapani Bandung dan Guru Agama Islam Sekolah Lanjutan Tingkat Pertama Luar Biasa Tunagrahita Ringan, ternyata program bimbingan sholat secara khusus bagi anak tunagrahita ringan hingga saat ini belum dimiliki.

Berdasarkan uraian di atas, maka penelitian ini perlu menjawab pertanyaan tentang bagaimana program bimbingan sholat bagi Anak Tunagrahita Ringan di SLB-BC Sumber Sari Antapani Bandung.

Untuk menjawab pertanyaan tersebut perlu mendeskripsikan dan menganalisis 
aspek-aspek sebagai berikut: kemampuan awal anak tunagrahita ringan dalam melaksanakan sholat; (2) upaya yang dilakukan oleh guru dalam membantu kemandirian sholat anak tunagrahita ringan; (3) upaya yang dilakukan oleh orang tua dalam membantu kemandirian sholat anak tunagrahita ringan; (4) kendala yang dialami oleh orang tua dan guru dalam melaksanakan bantuan kemandirian sholat anak tunagrahita ringan; (5) upaya yang dilakukan oleh orang tua dan guru dalam mengatasi kendala yang dialaminya.

\section{LANGKAH-LANGKAH PENELITIAN}

Penelitian ini menggunakan metode deskriptif analitik dengan pendekatan kualitatif. Adapun langkah - langkah penelitian ini adalah menggunakan alat pengumpul data yaitu melalui observasi, wawancara, dan studi dokumentasi.

Keseluruhan kegiatan penelitian ini dilaksanakan dalam beberapa tahap kegiatan, yakni tahap orientasi, tahap ekplorasi, tahap wawancara ulang (member check), tahap triangulasi dan tahap uji validasi.

\section{KAJIAN TEORI}

Edgar Doll (1951) mengetengahkan penjelasan tentang anak tunagrahita ringan sebagai berikut :

"The modern view of mental deficiency regards it as a condition rather than a disease. Six characteristics are commonly accepted as part of the complete concept, namely, (1) social incompetence, (2) mental incompetence, (3) deficiency or defect of development, (4) constitutional origien, (5) duration of adulthood (though commonly detected during pre-adolescent priod), and (6) essentially of impossibility of cure (though the consequence may be some what mitigated by suitable regimen".

Adapun orang-orang di negeri Inggris malah cenderung lebih menitik beratkan kepada aspek ketidak mampuan social, sebagaimana dinyatakan dalam The Mental Deficiency Act of 1927 sebagai berikut : mental dectiveness means a condition of arrest or incomplete development of mind existing before the age of 18 years, either aristing from inherent causes or induced by diseases or injury.

Dalam penelitian ini penulis akan mengambil anak luar biasa yang mampu didik anak tunagrahita ringan (ATGR). Karena penulis pandang akan lebih memudahkan untuk diteliti dan tidak terlalu sulit untuk diterapkannya bimbingan sholat pada anak tunagrahita ringan (ATGR) ini.

Anak Luar Biasa mampu didik pada umumnya memiliki ciri-ciri sebagai berikut :

1. Mereka mampu menyelesaikan pelajarannya sampai setingginya tingkat kelas empat dengan usia 16 tahun;

2. Mereka pada umumnya masih akan belum mampu belajar untuk membaca atau untuk berhitung matematik secara formal sampai mencapai usia sekitar 9 12 tahun;

3. Mereka dapat mencapai dan menjalani tingkat perkembangan sekitar setengah hingga juga perempatnya kecepatan anak normal;

4. Kemajuan belajarnya disekolah dapat mencapai taraf setengah atau tiga perempat kemajuan anak lainnya yang normal;

5. Meskipun penguasaan bahasannya terbatas, namun untuk keperluan percakapan dan pergaulan kesehariannya akan cukup memadai;

6. Dalam berbagai hal pada umumnya mereka dapat bergaul dengan orangorang lainnya; dan

7. Mereka belajar untuk keperluan tugas pekerjaan kasar atau setengah terampil (semi-skills) dan biasanya dapat memadai untuk mendukung keperluan hidupnya pada tingkat usia dewasa.

Ada beberapa karakteristik anak tunagrahita ringan (ATGR), yang 
dikemukakan oleh Astati (1999:16 -12), yaitu :

Ciri fisik dan motorik. Keterampilan motorik anak tunagrahita ringan lebih rendah dari anak normal. Sedangkan tinggi dan berat badan adalah sama. Hasil penelitian Rarick (1980) yang dihimpun oleh Samuel A. Kirk (1986) menyimpulkan bahwa kesehatan tubuh dan kematangan motorik anak tunagrahita ringan lebih rendah dari pada anak normal yang sesuai dengannya.

Bahasa dan Penggunaannya. Anak Tunagrahita Ringan banyak lancar berbicara tetapi kurang dalam perbendaharaan kata. Mereka juga kurang mampu menarik kesimpulan mengenai apa yang dibicarakannya.

Kecerdasan. Anak tunagrahita mengalami kesukaran dalam berfikir abstrak. Tetapi mereka masih mampu mempelajari hal-hal akademik walaupun terbatas. Sebagian dari mereka mencapai usia kecerdasan yang sama dengan anak normal usia 12 tahun ketika mencapai usia dewasa. Tetapi sebagian lagi tidak dapat mencapai hal itu. Sebagaimana tertera dalam "The New American Ebster" (1956) yang di alihbahasakan oleh Amin (1994:35) menyatakan bahwa kecerdasan berpikir seorang tunagrahita ringan paling tinggi sama dengan kecerdasan anak normal usia 12 tahun. Di samping itu mereka menunjukkan keterbatasan lingkup perhatian, mudah terganggu perhatiannya, hiperaktif,dan pasif (diam berjam-jam).

Sosialisasi. Anak tunagrahita ringan cenderung menarik diri, acuh tak acuh, mudah bingung. Keadaan seperti ini akan bertambah berat apabila lingkungannya tidak memberikan reaksi positif. Mereka cenderung bergaul dengan anak normal yang lebih muda usianya. Tidak jarang dari mereka mudah dipengaruhi sebab mereka tidak dapat memikirkan akibat dari tindakannya.

Kepribadian. Ciri-ciri pribadi anak tunagrahita ringan (ATGR) antara lain: kurang percaya diri, merasa rendah diri, mudah prustasi. Cirri-ciri ini berkaitan dengan reaksi orang lain terhadap kondisi mereka karena orang lain mereaksi berdasarkan pada keterampilan penyesuaian diri dan pola perilakunya. Sedangkan anak-anak tunagrahita tidak dapat memenuhi harapan orang lain karena kecacatannya. Misalnya dalam berbahasa atau berprilaku timbul pengulangan, dan mudah stress. Seperti yang dikemukakan Bill R. Grearheart (1976) bahwa anak tunagrahita ringan mudah prustasi, dan minat mereka kurang terutama dalam hal yang membutuhkan pikiran.

Pekerjaan. Dalam kemampuan kerja anak tunagrahita ringan dapat melakukan pekerjaan yang semi skilled dan pekerjaan sederhana, bahkan sebagian besar dari mereka dapat mandiri dalam melakukan pekerjaan sebagai orang dewasa asalkan sesuai dengan kemampuannya. Apoloni (1981) menyatakan bahwa hal yang esensial dalam persiapan vokasional adalah adanya keseuaian antara keterampilan dasar dengan lapangan pekerjaan.

Faktor Endogen. Adapun yang termasuk ke dalam faktor endogen itu pada pokoknya bersifat herediter atau bertalian erat dengan permasalahan keturunan atau bawaan dengan kelahiran para penyandang tunagrahita itu sendiri. Hal itu berarti faktor tua dapat menjadi sumber penyebab ketunagrahitaan. Dari keseluruhan faktor penyebab ketunagrahitaan itu ternyata faktor endogen ini menempati posisi yang sangat determinan, karena hampir sekitar $30-75 \%$ kontribusi relatifnya terhadap peristiwa ketunagrahitaan. Di antaranya dalam faktor endogen ini lebih banyak terjadi pada orang tua yang melakukan perkawinan yang masih mempunyai pertalian hubungan kekeluargaan atau sedarah yang sangat dekat (degree of blood relationship).

Ketunagrahitaan bersifat endogen ini, juga mudah dikenali karena pada umumnya disertai dengan tanda-tanda kelainan fisik, seperti antara lain fenomena, 
mongolism, cretibism, hydrosephaly, microcephaly dan sebagainya.

Faktor Eksogen. Faktor eksogen ini mungkin terjadi karena berbagai peristiwa pula, seperti waktu kelahiran, kecelakaan, dan faktor-faktor yang tidak terduga lainnya. Di antaranya seperti terjadinya infection, trauma, toxic (keracunan), endocrine, deprivation, dan sebagainya. Meskipun prosesnya sebagian terjadi dalam tubuh ibu hamil dari sumber eksogen.

Sehubungan dengan kemampuan yang dimiliki oleh Anak tunagrahita ringan terbatas, maka ini dapat menimbulkan berbagai masalah seperti dalam bimbingan sholat. Walaupun usia dan perkembangan fisik bertambah tetapi kemampuan intelektual anak tunagrahita ringan masih kurang dibanding dengan anak normal. Oleh karena itu, anak tunagrahita ringan memerlukan bantuan secara khusus.

\section{Penggunaan Waktu}

Anak tunagrahita ringan tergolong anak yang mempunyai kemampuan untuk di didik. Dalam artian mereka masih bias untuk mengikuti pendidikan di SLB. Akan tetapi karena keterbatasan intelektualnya maka dalam proses belajar mengajarpun akan memerlukan waktu yang cukup banyak.

Dalam bimbingan sholat, khususnya untuk anak tunagrahita ringan dalam memahami satu materi saja dari seorang pembimbing mereka harus betul-betul memerlukan banyak. Contohnya materi tentang niat sholat saja mereka tidak cukup satu kali, tetapi memerlukan minimalnya lima kali pertemuan dan dalam penyampaiannyapun harus tampak jelas, lugas dan mudah dimengerti oleh anak tunagrahita ringan.

\section{Layanan Bimbingan Konseling}

Ada dua pendekatan dalam bimbingan dan konseling yaitu (1) pendekatan individual. Dalam pendekatan ini seorang konselor hanya menghadapi seorang individu atau konseli dalam sisisisinya. Dalam pendekatan individual ini terdiri atas dua tahap, yaitu tahap membangun hubungan dan tahap aksi. (2) pendekatan kelompok. Dalam pendekatan ini seorang konselor bukan hanya menghadapi seorang klien, melainkan beberapa klien pada waktu yang sama. Jadi pesan konselor tidak jauh berbeda dengan tugas guru, ia menyampaikan informasi dan menunjukkan cara-cara mengambil keputusan. Fokusnya ialah para siswa, informasi yang diberikan dengan cara-cara memecahkan masalah yang berkenaan dengan tugas-tugas perkembangan dan tugas sosial.

\section{Orang Tua}

Orang tua merupakan pendidikan pertama dan utama dalam perkembangan anak tunagrahita ringan. Maka peran orang tua sangatlah penting untuk membimbing anaknya secara tepat dan terarah.

\section{Materi}

Anak tunagrahita ringan sangatlah sulit untuk memahami sesuatu yang bersifat abstrak, mereka akan lebih mudah memahami sesuatu yang mudah dilihat oleh mata dan tidak terlalu banyak menggunakan intelektualnya. Oleh karena itu, bagaimana seorang pembimbing menyederhanakan materi dalam setiap pertemuannya.

\section{Fungsi Bimbingan Keagamaan di Sekolah bagi Anak Tunagrahita Ringan}

Sekolah merupakan lembaga pendidikan formal yang mempunyai program yang sistemik dalam melaksanakan bimbingan, pengajaran dan latihan kepada anak (siswa) agar mereka berkembang sesuai dengan potensinya. Menurut Hurlock (1959:561) pengaruh sekolah terhadap perkembangan kepribadian anak sangat besar, karena sekolah merupakan substitusi dari keluarga dan guru-guru substitusi dari orang tua.

Syamsu Yusuf LN (2000:140) menegaskan bahwa guru agama dituntut 
untuk memiliki karakteristik sebagai berikut: (1) kepribadian yang mantap (akhlak mulia), (2) menguasai disiplin ilmu dalam bidang studi Pendidikan Agama Islam, dan (3) memahami ilmu-ilmu lain yang relevan atau menunjang kemampuannya dalam mengelola proses belajar-mengajar seperti psikologi pendidikan, bimbingan konseling, metodologi pengajaran, administrasi pendidikan, teknik evaluasi dan psikologi agama.

\section{Tujuan Pendidikan Agama Islam}

Tujuan pendidikan agama Islam di SLB-BC secara umum adalah meningkatkan keimanan, pemahaman, penghayatan dan pengamalan siswa tentang Agama Islam sehingga menjadi manusia muslim yang beriman dan bertaqwa kepada Allah SWT serta berakhlak mulia dalam kehidupan pribadi, bermasyarakat, berbangsa dan bernegara.

\section{Program Bimbingan Keagamaan}

Program Bimbingan keagamaan untuk SLTPLB khususnya tunagrahita ringan telah dikemukakan dalam GBPP (1995:2) yaitu memiliki fungsi sebagai berikut : (1) pengembangan, yaitu untuk meningkatkan keimanan dan ketakwaan siswa kepada Allah SWT yang telah ditanamkan dalam lingkungan keluarga, (2) penyaluran, yaitu untuk menyalurkan siswa yang memiliki bakat khusus di bidang agama agar bakat tersebut dapat berkembang secara optimal, (3) Perbaikan, yaitu untuk memperbaiki kesalahankesalahan, kekurangan-kekurangan dan kelemahan-kelemahan siswa dalam keyakinan, pemahaman dan pengamalan ajara agama Islam dalam kehidupan seharihari, (4) Pencegahan, yaitu untuk menangkal hal-hal negatif dari lingkungannya atau dari budaya asing yang dapat membahayakan dan menghambat perkembangan dirinya, (5) Penyesuaian, yaitu untuk menyesuaikan diri dengan lingkungannya baik lingkungan fisik atau lingkungan social dan dapat mengubah lingkungannya sesuai dengan ajaran Islam, (6) Sumber nilai, yaitu memberikan pedoman hidup untuk mencapai kebahagiaan hidup di dunia dan akhirat, (7) Pengajaran, yaitu menyampaikan pengetahuan keagamaan yang fungsional, dan (8) Sumber motivasi, yaitu untuk memberikan dorongan kepada siswa yang menyandang cacat khususnya Tunagrahita Ringan untuk menumbuhkankembangkan rasa percaya diri, berpegang kepada keyakinan atas kekuasaan serta sifat rahman dan rahim Allah Swt.

\section{Hasil Penelitian dan Pembahasan}

Peneliti akan menjelaskan hasil-hasil dari observasi, wawancara dengan orang tua siswa, anak tunagrahita ringan, dan guru agama. Deskripsi data penelitian ini meliputi :

\section{Kemampuan awal yang telah dimiliki oleh anak tunagrahita ringan Tentang Sholat}

\section{a. Responden RH}

Kemampuan awal sholat yang dimiliki oleh responden RH masih belum sesuai dengan ketentuan agama Islam, dikarenakan yang bersangkutan mengalami kekurangan dalam perhatian dan intelektualnya. Ia mengalami kesulitan ketika akan melakukan sholat. Bantuan yang diberikan oleh orang tua responden RH belum maksimal, disebabkan keterbatasan kemampuan orang tua dalam memahami ketunagrahitaan dan tata cara sholat yang sesuai dengan ketentuan Islam. Bantuan yang diberikan pun belum tepat.

\section{b. Responden DAJ}

Kemampuan awal sholat yang telah dimiliki oleh responden DAJ sudah banyak yang sesuai dengan ketentuan agama Islam. Ini disebabkan karena ketelatenan dan keuletan dari responden ketika menerima bantuan kemandirian sholat baik dari orang tua 
atau dari gurunya. Adapun bantuan yang diberikan oleh kedua orang tuanya adalah dalam bentuk selalu mengajak sholat berjamaah, memberikan gambargambar tentang tata cara sholat dan mengundang guru ngaji di rumahnya.

\section{c. Responden FAT}

Orang tua memberikan bantuanya kepada responden FAT cukup serius, seperti memberikan waktu khusus dan sholat berjamaah. Orang tua responden FAT mempunyai kemampuan sedikit tentang ketunagrahitaan dan sholat. Dalam bantuan kemandirian sholat, orang tua telah membuat program di rumah dan telah mengundang guru ngaji.

\section{d. Responden IKH}

Banyak kemampuan awal sholat yang telah dimiliki oleh responden IKH sesuai dengan ketentuan, baik gerakan dan bacaan wudlu atau gerakan dan bacaan dalam sholat. Ini disebabkan dari kemampuan responden IKH itu sendiri dalam memperhatikan semua bentuk bantuan dari orang tua dan guru tentang sholatnya, serta seringnya melakukan sholat berjamaah dengan teman-temannya di masjid.

Bantuan yang diberikan oleh orang tua adalah mengajak sholat berjamaah, memberi buku-buku bacaan tentang tata cara sholat, memberikan kawan untuk diskusi, dan mengundang guru ngaji di rumah. Sehingga bantuan kemandirian sholat bagi responden IKH hampir terprogram secara sistematis. Dan ini memberikan ingatan yang lama pada responden IKH, sehingga dapat melakukan sholat dengan kesadaran sendiri.

\section{PEMBAHASAN HASIL PENELITIAN}

Setelah penulis melakukan penelitian dengan mengumpulkan data-data, baik melalui wawancara dan observasi, perlu dibahas tentang hasil penelitian tersebut.

Dari laporan studi kasus di atas didapat bahwa ada beberapa anak tunagrahita ringan di kelas 2 dan kelas 3 SLTP-LB Sumber Sari Antapani Bandung, belum mempunyai kemampuan tentang sholat dan wudlunya baik mengenai gerakannya ataupun bacaannya.

Dari responden dalam penelitian ini ada di antaranya responden yang sudah memiliki kemampuan sholat dan wudlunya dalam bentuk gerakan secara tertib, tetapi dalam bacaannya masih banyak yang belum bisa seperti do'a niat sholat lima waktu, do'a setelah wudlu, do'a iftitah, do'a tasyahud akhir. Sebaliknya ada juga responden yang mempunyai kemampuan yang berbeda dengan kawan-kawan yang lainnya dalam segala hal seperti dalam wudlu dan sholat, berkaitan dengan gerakannya ataupun bacaannya dia sudah dapat melakukannya walaupun belum muncul kesadaran diri untuk melaksanakan sholat. Seperti pada responden IKH dalam gerakan wudlu bisa melakukannya dengan tertib dan juga dalam gerakan sholatnya. Adapun mengenai bacaan-bacaan sholat dan wudlu sudah banyak yang hafal secara tepat seperti do'a niat wudlu, do' aberdiri setelah ruku, do'a sujud, do'a duduk diantara sujud dan ucapan salam.tetapi bacaan taysahud awal dan akhir masih harus di tuntun oleh orang tua atau guru secara bersama-sama.

Berdasarkan penjelasan kasus di atas ini sepertinya tidak sesuai dengan perkembangan remaja pada umumnya, sebagaimana Syamsu Yusuf LN. (2000:7982) menjelaskan tugas-tugas perkembangan remaja diantaranya adalah mencapai kemandirian emosional dari orang tua dan orang dewasa.

Hakekat tugas. Tujuan dari tugas perkembangan ini adalah membebaskan diri dari sikap dan perilaku yang kekanak-kanakkan atau bergantung kepada orangtua; (2) mengembangkan afeksi (cinta kasih) kepada orangtua, tanpa bergantung (terikat) kepadanya, dan (3) mengembangkan sikap respek terhadap orang dewasa lainnya tanpa bergantung kepadanya.

Dasar biologis. Secara biologis, remaja sudah dapat mencapai tugas 
perkembangan ini, karena mereka telah memperoleh kematangan seksualnya.

Dasar psikologis. Dalam masyarakat, baik remaja maupun orangtua merasa takut, cemas, dan bingung untuk mengatasi tugas ini secara psikologis mereka mengalami ambivalensi (sikap mendua).

$$
\text { Tingkat pencapaian tugas }
$$

perkembangan.

Berdasarkan teori perkembangan sepertinya mereka belum mencapai perkembangan secara optimal padahal usia mereka berkisar dari $14-18$ tahun yang kesemuanya menduduki kelas 2 dan 3 SLTP-LB.

Kalau dikelompokkan kedalam pencapaian tugas perkembangan remaja, maka mereka tergolong pada tingkat pencapaian tugas perkembangan yang paling rendah, ini dikarenakan dari kemampuannya dalam melakukan sholat belum bisa mandiri masih bersifat kekanak-kanakkan, dalam artian masih selalu bimbingan dari orangtua dan gurunya.

\section{SIMPULAN}

Dari hasil penelitian di SLB-BC Sumber Sari Antapani Bandung dapat di jelaskan sebagai berikut:

\section{Pencapaian kemampuan awal sholat anak tunagrahita ringan}

Kemampuan yang telah dimiliki oleh anak tunagrahita ringan sangat beragam dari mulai yang sudah bisa melakukan wudlu dan sholat baik mengenai gerakannya ataupun bacaannya.

Tetapi ada juga yang sama sekali belum bisa melakukan sholat dengan tepat sesuai dengan ketentuan, dimulai dari gerakan wudlu maupun sholatnya. Apalagi bacaan-bacaan sholat mereka tidak bisa mengungkapkannya dengan tepat sesuai dengan ketentuan agama.

Faktor penyebabnya ini dari anak tunagrahita ringanitu sendiri, karena memiliki kemampuan intelektualnya yang kurang, sehingga menyulitkan mereka dalam mengingat, menghafal dan memahami sesuatu yang abstrak.

2. Perlakuan guru dalam membantu kemandirian sholat anak tunagrahita ringan

Guru agama Islam masih belum optimal melakukan bantuan bimbingan kemandirian sholat pada anak tunagrahita ringan, ini terlihat sampai sekarang anak tunagrahita ringan masih belum mampu, tepat, dan sesuai dengan ketentuan ketika melakukan wudlu dan sholat.

Faktor penyebabnya adalah dikarenakan belum adanya suatu program secara khusus tentang bimbingan sholat yang dimasukkan dalam kurikulum atau ekstrakurikuler. Jadi guru hanya melakukan bimbingan pada materi yang telah ada pada kurikulum yang ada.

3. Perlakuan orang tua dalam membimbing sholat anak tunagrahita ringan

Bimbingan sholat yang pernah dilakukan oleh orang tua dari anak tunagrahita ringan sangat beragam dari yang mulai membimbing secara serius sampai kepada orang tua yang tidak terlalu memperhatikan sholat anaknya.

Ada orang tua yang telaten mereka mau membimbing dari mulai cara berwudlu dan cara melakukan sholat yang baik dan benar sesuai dengan ketentuan, seperti cara mencuci tangan, sampai pada cara mencuci kedua kaki, sekaligus bacaan dalam wudlu. Dan cara melakukan gerakan dan bacaan dalam sholat yaitu dari mulai berdiri menghadap kiblat sampai salam akhir berikut bacaannya.

4. Kendala orang tua dan guru dalam membantu kemandirian sholat anak tunagrahita ringan

Kendala yang dialami oleh orang tua dapat dikelompokkan kepada tiga kendala yaitu pertama dari anak tunagrahita ringan itu sendiri. Ini disebabkan karena mereka memiliki 
kelainan intelektual, sehingga dalam melakukan pemahaman yang abstrak sangat sulit. Kedua dari orang tua, ini dimulai dari orang tua yang tidak mampu memahami tentang anak tunagrahita ringan atau ada juga yang karena belum bisa sholat secara tepat sesuai dengan ketentuan. Ketiga bersumber dari sekolah itu sendiri, ini dikarenakan belum adanya program bimbingan sholat yang diterapkan pada sekolah luar biasa untuk anak tunagrahita ringan.

5. Upaya orang tua dan guru dalam mengatasi kendala yang dihadapinya.

Ada upaya yang dilakukan oleh orang tua dan guru dalam mengatasi kendala ketika melakukan bantuan kemandirian sholat pada anak tunagrahita ringan. Adapun upaya tersebut adalah sebagai berikut : (1) Memanggil ustadz, (2) dimasukkan ke SLB-C, (3) mengundang para ortopedagog tunagrahita ringan, dan (4) mendiskusikan dengan teman-teman yang memiliki kemanpuan tentang tata cara sholat bagi ketunagrahitaan

\section{SARAN}

Berdasarkan hasil penelitian ini dapat menghasilkan suatu program hipotetik yang diharapkan dapat meningkatkan kemampuan orang tua dan guru dalam membimbing sholat anak tunagrahita ringan, maka daripada itu perlu direkomendasikan.

\section{Saran menyangkut kualitas program hipotetik}

Program hipotetik yang telah penulis rumuskan sebagai saran kepada orang tua dan guru yaitu program bimbingan sholat yang dapat meningkatkan kemampuan orang tua dan guru dalam membantu kemandirian sholat anak tunagrahita ringan. Saya yakin masih terdapat banyak kekurangan baik dikarenakan keterbatasan kemampuan peneliti atau mungkin keterbatasan fasilitas yang digunakan oleh peneliti.

2. Saran untuk Sekolah Luar Biasa C (Tunagrahita)

Sekolah harus dapat mengoptimalkan orang tua dan adanya kerjasama antara orang tua dan guru agama sehingga dapat terjalin efektifitas bimbingan kemandirian sholat pada anak tunagrahita ringan. Untuk tercapainya sholat yang baik pada anak tunagrahita ringan, maka perlu diadakannya program bimbingan sholat secara intensif seperti adanya wajib sholat berjamaah setiap dzuhur.

3. Saran untuk peneliti selanjutnya

Masih banyak aspek yang belum disentuh oleh peneliti dalam penelitian kali ini, maka saya berharap peneliti selanjutnya dapat melanjutkan penelitian ini, seperti dari aspek kerjasama antara guru dengan orang tua dalam bimbingan dan pengaruhnya terhadap anak tunagrahita ringan.

4. Saran untuk orang tua siswa tunagrahita ringan

Untuk dapat melaksanakannya dengan baik, saya harap perlu adanya kerjasama antara orang tua, anak tunagrahita ringan, dan guru. Karena ketiga faktor ini sangat menentukan dalam keberhasilan program.

\section{Saran untuk Guru}

Guru merupakan seorang yang banyak di ikuti oleh siswa maka perlu adanya program sholat berjamaah minimal dua kali dalam seminggu. Ini akan membantu keberhasilan dari sholat anak tunagrahita ringan secara baik dan benar sesuai dengan ketentuan.

\section{DAFTAR PUSTAKA}

Ahmadi, A. (1991). Psikologi Sosial. Jakarta: PT. Rineka Cipta

Ahmad, Idris. (2002). Upaya Guru Dalam Membimbing Keterampilan Sosial Siswa Tunagrahita Sedang (Tesis). Bandung: UPI. 
Ali, Daud Muhammad. (1998). Pendidikan Agama Islam. Jakarta: Rajawali Pers.

Amin, Moh. (1989). Pendidikan Luar

Biasa II. Alihbahasa. Jakarta: DNIKS.

(1995). Ortopedagogik Anak Tunagrahita. Jakarta: Depdikbud Dikti. Proyek Pendidikan Tenaga Guru.

Amin, Sidik. (2000). Tata Cata Sholat. Bandung: Persis.

Aripin. (2000). Manusia dan Pendidikan. Jakarta : Al-Husna Zikra.

Ashman, A. and Elkins, J. (eds). (1994). Education Children With Special Needs. Sidney: Prentice Hall Of Australia Pty Ltd.

Astati. (1999). Program Layanan dasar Bimbingan dan Konseling Dalam Meningkatkan Kesiapan Kerja Anak Tunagrahita Ringan (Tesis). Bandung: UPI.

Azra, Azumardi. (1996). Pendidikan dalam Keluarga Muslim. Jakarta: Rajawali Pers.

Chance, Paul. (1994). Learning and Behaviour. (Third Edition). California: Brooks/Cole Publishing Company.

Departemen Pendidikan dan Kebudayaan. (1995). Kurikulum Pendidikan Luar Biasa. Jakarta.

Departemen Agama RI. (1971). Al-Qur'an dan Terjemahnya. Jakarta.

Efendi, Jon. (1999). Pengembangan Program Bimbingan Konseling Perkembangan Melalui Kegiatan Belajar Mengajar Dalam Peningkatan Kemandirian Anak Tunagrahita Ringan. (Tesis). UPI.

Hardman, Michael L., Drew, Clifford J., Wolf, Barbara. (1990). Human Exceptionality. Third Edition. Massachu Setts: Allyn and Bacon A Division of Simon \& Schuster Inc.

Hawari, Dadang. (1996). Al-Qur'an Ilmu Kedokteran Jiwa dan Kesehatan
Jiwa. Yogyakarta: PT. Dana Bhakti Prima Yasa.

Hurlock, Elizabet. (1950). Child Development. New York. McGraw Hill Book Company. Inc.

Jalaluddin, Rahmat. (2001). Teologi Pendidikan. Jakarta: Rajawali Pers.

Kerlinger, FN. (1973). Foundation of Behavioral Reseach. (Second Edition). New York University.

Kirk, Samuel A \& Gallagher, James J. (1979). Educating Exceptional Perspective. England: Pergamen Press Hedington Hill Hall.

Langgulung, Hasan. (1995). Manusia dan Pendidikan Suatu Analisa Psikologi dan Pendidikan. Jakarta: Al-Husna Zikra.

Mangungsong, Frieda. (1998). Psikologi dan Pendidikan Anak Luar Biasa. Jakarta: LPSP3 UI.

Moloeng, LJ. (1989). Metodologi Penelitian dalam Pendidikan. Bandung: Rosdakarya.

Mujib, A. (1999). Fitrah dan Kepribadian Islam. Jakarta: Darul Falah.

Natawidjaja, Rohman. (1987). Pendekatan-pendekatan Dalam Penyuluhan Kelompok. Jakarta: PLPTK Depdikbud.

(1988). Peranan Guru dalam Bimbingan di Sekolah. Bandung: CV. Abardin.

Nurihsan, Juntika. (2002). Pengantar Bimbingan dan Konseling. UPT Layanan Bimbingan dan Konseling UPI.

Parawansa, Indar Khofifah. (2001). Peningkatan Pemahaman Masyarakat Tentang Keberadaan Penyandang Tunagrahita Dalam Kaitannya dengan Perwujudan HAM. Disampaikan dalam seminar FNKCM di Uninus.

Rakhmat, Jalaluddin dan Gandaatmaja, Mukhtar. (1994). Keluarga Muslim Dalam Masyarakat Modern. Bandung: Rosda Karya. 
Ridwan. (1988). Metodologi Penelitian. Bandung: Rineka Cipta.

Rifa'I, M. (1976). Risalah Tuntunan

Shalat Lengkap. Semarang: PT. Karya Toha Putra.

Sabiq, Sayyid. (1996). Fikih Sunnah. Bandung: PT. Al-Ma'arif.

Suhaeri dan Purwanta, Edi. (1996).

Bimbingan dan Konseling Anak Luar Biasa. Departemen Pendidikan dan Kebudayaan. Jakarta.

Supratiknya. (1995). Mengenal Prilaku

Abnormal. Penerbit Kanisius:

Universitas Sanata Dharma

Yogyakarta.
Surya, Muhammad. (1994). Dasar-dasar Konseling Pendidikan. Bandung: Bhakti Winaya.

Syamsuddin, Abin. (2001). Penyandang Tunagrahita dan Permasalahannya. Disampaikan dalam Seminar FNKCM di Uninus.

Tafsir, Ahmad. (1987). Ilmu Pendidikan Islam Dalam Perspektif Islam. Bandung: Remaja Rosdakarya.

Ulwan, Nashih, Abdullah. (1995). Pendidikan Anak Dalam Islam. Jakarta: Pustaka Amami.

Yusuf, Syamsu LN. (2000). Psikologi Perkembangan Anak dan Remaja. Bandung: Rosda Karya. 